\title{
Pph3 Dephosphorylation of Rad53 Is Required for Cell Recovery from MMS-Induced DNA Damage in Candida albicans
}

\author{
Haitao Wang ${ }^{1}$, Jiaxin Gao ${ }^{1}$, Wanjie $\mathrm{Li}^{1}$, Ada Hang-Heng Wong ${ }^{2}$, Kangdi Hu${ }^{1}$, Kun Chen ${ }^{1}$, Yue Wang ${ }^{3 *}$, \\ Jianli Sang ${ }^{1 *}$
}

1 Key Laboratory of Cell Proliferation and Regulation Biology, Ministry of Education, College of Life Sciences, Beijing Normal University, Beijing, People's Republic of China, 2 Protein Science Laboratory, School of Life Sciences, Tsinghua University, Beijing, China, $\mathbf{3}$ Institute of Molecular and Cell Biology, Agency for Science, Technology and Research (A*STAR), Singapore, Singapore

\begin{abstract}
The pathogenic fungus Candida albicans switches from yeast growth to filamentous growth in response to genotoxic stresses, in which phosphoregulation of the checkpoint kinase Rad53 plays a crucial role. Here we report that the Pph3/Psy2 phosphatase complex, known to be involved in Rad53 dephosphorylation, is required for cellular responses to the DNAdamaging agent methyl methanesulfonate (MMS) but not the DNA replication inhibitor hydroxyurea (HU) in C. albicans. Deletion of either $P P H 3$ or PSY2 resulted in enhanced filamentous growth during MMS treatment and continuous filamentous growth even after MMS removal. Moreover, during this growth, Rad53 remained hyperphosphorylated, MBFregulated genes were downregulated, and hypha-specific genes were upregulated. We have also identified S461 and S545 on Rad53 as potential dephosphorylation sites of Pph3/Psy2 that are specifically involved in cellular responses to MMS. Therefore, our studies have identified a novel molecular mechanism mediating DNA damage response to MMS in C. albicans.
\end{abstract}

Citation: Wang H, Gao J, Li W, Wong AH-H, Hu K, et al. (2012) Pph3 Dephosphorylation of Rad53 Is Required for Cell Recovery from MMS-Induced DNA Damage in Candida albicans. PLoS ONE 7(5): e37246. doi:10.1371/journal.pone.0037246

Editor: Neeraj Chauhan, New Jersey Medical School, University of Medicine and Dentistry of New Jersey, United States of America

Received December 4, 2011; Accepted April 16, 2012; Published May 14, 2012

Copyright: (c) 2012 Wang et al. This is an open-access article distributed under the terms of the Creative Commons Attribution License, which permits unrestricted use, distribution, and reproduction in any medium, provided the original author and source are credited.

Funding: The National Basic Research Program of China (no. 2007CB914401) and The Fundamental Research Funds for the Central Universities (no. 105566GK). The funders had no role in study design, data collection and analysis, decision to publish, or preparation of the manuscript.

Competing Interests: The authors have declared that no competing interests exist.

*E-mail: jlsang@bnu.edu.cn (JS); mcbwangy@imcb.a-star.edu.sg (YW)

\section{Introduction}

Candida albicans is a pleiomorphic fungus that can grow in three different morphological forms: budding yeast, pseudohyphae and hyphae $[1,2]$, rendering it an excellent model for studying cell morphogenesis [2-5]. The yeast-to-hyphal growth transition has been implicated in its virulence in various human superficial infections of the skin, vagina and oral epithelia [5-9]. Therefore, understanding the underlying mechanisms that regulate the morphological transition may provide key insights into potential strategies for developing antifungal therapeutics.

Earlier studies showed that the cAMP/protein kinase A (PKA) and mitogen-activated protein (MAP) kinase pathways play key roles in regulating the hyphal growth of $C$. albicans $[7,10,11]$. Recently, many studies revealed cell cycle checkpoints as part of alternative regulatory pathways mediating filamentous growth under various conditions that block cell cycle progression $[12,13]$. For example, depletion of the G1 cyclin Gln3 [14,15], or the mitotic cyclin Clb2 or Clb4 [16], or deletion of other cell cycle regulatory genes such as $C D C 4$ or $C D C 5$ were shown to result in filamentous growth $[17,18]$. Filamentous growth was also observed in several C. albicans deletion mutants defective in DNA damage repair $[19,20]$. DNA damaging agents were found to cause cell cycle arrest and filamentous growth in a manner dependent on the DNA damage/replication checkpoint kinase Rad53 [21].
Rad53, the yeast homolog of human Chk2 [22,23], is a Ser/Thr kinase that plays a pivotal role in $\mathrm{G} 2 / \mathrm{M}$ checkpoint regulation by phosphorylating various substrates involved in cell cycle progression and/or DNA damage repair [24-26]. Hyperphosphorylation of Rad53 is sufficient for cell cycle arrest and its dephosphorylation leads to recovery after genotoxic stress [2729]. Previous studies revealed diverse phosphorylation and dephosphorylation patterns on Rad53 under different circumstances. The phosphorylation mainly occurs in the two SQ cluster domains (SCDs). The N-terminal SCD is conserved in human Chk2, while the C-terminal SCD is unique to the yeast homologs. Several protein kinases such as Mec1, Mrcl and $\operatorname{Rad} 9$ [27,30-32] and phosphatases Pph3 and Ptc2 are involved in regulating Rad53 phosphorylation [28,33,34]. However, the sites of phosphorylation/dephosphorylation by different kinases and phosphatases and their regulation and biological significance of the phosphorylation state of particular sites remain largely unknown. It was reported that Pph3 binds to the central kinase domain of Rad53, while Ptc2 binds to its FHAl domain, and that their deletion led to sensitivity to different genotoxic stresses [35]. However, the underlying molecular mechanisms remain elusive.

In this study, we examined the role of the phosphatase Pph3/ Psy2 in regulating cellular responses to MMS and HU in $C$. albicans. We investigated how deletion of the phosphatase genes affected Rad53 phosphorylation and its ability to regulate 
downstream signaling and cell morphogenesis. We also obtained evidence on the potential sites for Pph3/Psy2 dephosphorylation on $\operatorname{Rad} 53$.

\section{Results}

\section{pph3 $\triangle$ and psy2 $\triangle$ mutants exhibited hypersensitivity to MMS but not $\mathrm{HU}$}

Previous studies in Saccharomyces cerevisiae demonstrated that PPH3 deletion led to hypersensitivity towards MMS but not HU [34]. Thus, we first determined whether the same phenomenon also occurs in C. albicans. Wild-type, pph3 $\Delta$ and psy $2 \Delta$ yeast cells (Table 1) were inoculated into liquid YPD medium containing different concentrations of MMS or $\mathrm{HU}$ and incubated at $30^{\circ} \mathrm{C}$ for $6 \mathrm{~h}$, followed by recovery in fresh drug-free YPD medium for $8 \mathrm{~h}$ at $30^{\circ} \mathrm{C}$. Microscopic examination of the genotoxin-induced cell elongation at timed intervals revealed that both pph3 $\Delta$ and psy2 24 mutants exhibited cell elongation during $\mathrm{HU}$ treatment and returned to the yeast form of growth after drug removal in manners comparable to wild-type cells (Fig. 1A, left \& Fig. S2). In comparison, during MMS treatment the mutant cells exhibited faster elongation than wild-type cells and continued to elongate throughout the entire recovery period, while the wild-type cells returned to yeast growth $\sim 2 \mathrm{~h}$ after shifting to the drug free medium (Fig. 1A, right \& Fig. S1).

Flow cytometry analysis showed that wild-type cells were arrested with a 2C DNA content after $2 \mathrm{~h}$ MMS treatment, but pph3 4 and psy $2 \Delta$ mutants appeared to progress slowly through or arrested in $\mathrm{S}$ phase (Fig. 1B, left). In comparison, all three strains responded similarly to $\mathrm{HU}$ treatment, exhibiting a slow progression through $\mathrm{S}$ phase (Fig. 1B, right). In addition, both the pph $3 \Delta$ and psy $2 \Delta$ mutants reentered the cell cycle $4 \mathrm{~h}$ after $\mathrm{HU}$ removal (Fig. 1C, right), but remained arrested in $\mathrm{S}$ phase even $4 \mathrm{~h}$ after MMS removal (Fig. 1C, left).

Furthermore, wild-type cells adapted to MMS after several hours as reported for $S$. cerevisiae [37,38]. Even in the continuous presence of the genotoxin, wild-type cells were able to exit from the DNA damage-induced cell cycle arrest, re-enter the cell cycle, and switch from filamentous growth back to yeast growth (Fig, S1). In contrast, pph3 $\Delta$ and psy $2 \Delta$ cells remained arrested and continued to elongate for a long period of time before finally losing viability. This phenomenon was not observed with $\mathrm{HU}$ treatment (Fig. S2). Hence, we conclude that Pph3/Psy2 has a role in regulating cellular response to MMS but not $\mathrm{HU}$ in C. albicans.

\section{Deletion of $P P H 3$ and $P S Y 2$ resulted in Rad53 hyperphosphorylation}

Rad53 was shown to be a substrate of the Pph3/Psy2 complex in both S. cerevisiae and C. albicans [34,38]. Furthermore, Rad53 hyperphosphorylation was shown to cause cell cycle arrest and filamentous growth in C. albicans [38]. Next, we examined the phosphorylation state of Rad53 in response to MMS and HU treatment. Western blotting of C-terminally Myc-tagged Rad53 demonstrated that in wild-type cells Rad53 was hyperphosphorylated after both MMS (Fig. S3B) and HU treatment (Fig. $\mathrm{S} 3 \mathrm{~A}$ ), and became dephosphorylated $6 \mathrm{~h}$ after HU or MMS removal (Fig. 2A\&B). Both pph3 $\triangle$ and psy $2 \Delta$ mutants also showed a similar course of Rad53 dephosphorylation after HU removal (Fig. 2A). However, Rad53 hyperphosphorylation persisted in pph3 4 and psy $2 \Delta$ mutants even at $6 \mathrm{~h}$ after MMS removal (Fig. 2B), indicating that Rad53 dephosphorylation during recovery from MMS treatment is dependent on the Pph3/Psy2 complex.

\section{Deletion of $P P H 3$ and $P S Y 2$ resulted in dysregulated gene expression}

Next, we investigated the physiological significance of Rad53 hyperphosphorylation. Swi6p was demonstrated in S. cerevisiae to be phosphorylated by Rad53 to trigger G1 arrest by inhibiting the transcriptional activity of MBF $[39,40]$. MBF is the Mbpl/Swi6 transcriptional complex that regulates the expression of various genes related to cell cycle progression. Therefore, we examined the expression of MBF-regulated genes [40-42] by RT-PCR, qPCR and Northern blot analysis in C. albicans during MMS treatment and the recovery from it.

Results showed that there is an overall downregulation of MBFregulated genes, such as $M S H 2, R F A 2, C C N 1$ and PCL2, upon MMS treatment and during recovery in the pph3A or psy $2 \Delta$ mutant as compared to wild-type cells (Fig. 3A\&B). Upon MMS treatment, upregulation of MSH2, RFA2 and CCN1 was observed in wild-type, but to a minor level in the pph3 $\Delta$ and psy $2 \Delta$ mutant; while PCL2 was downregulated in all three strains (Fig. $3 \mathrm{~A}-\mathrm{C}$ ). Higher than normal levels of MSH2, CCN1 and RFA2 persisted in wild-type cells after recovery, while RFA2 returned to normal levels in the pph3 $\Delta$ and psy $2 \Delta$ mutant during recovery (Fig. 3B\&C). In contrast, PCL2 exhibited higher-than-normal expression levels after MMS recovery in wild-type cells, but exhibited near normal expression levels after recovery in the pph3 $\Delta$ and psy2 $\Delta$ mutant (Fig. 3B\&C). Negative controls without reverse transcriptase was used in the RT-PCR experiments to rule out genomic DNA contamination during PCR amplification (Fig. 3A). GADPH was used as loading control, and rRNA was included to indicate RNA integrity in Northern blot experiment (Fig. 3B).

Because filamentous growth was observed after MMS treatment, we also examined the expression of several known hyphaspecific genes including $H W P 1, E B P 1, E C E 1, A L S 3, S A P 4$ and UME6. Interestingly, expression of hypha-specific genes was significantly higher in pph3 $\Delta$ and psy $2 \Delta$ cells than in wild-type cells during MMS recovery (Fig. 3A\&B). Hence, this phenomenon is consistent with the observed cell elongation in C. albicans upon MMS treatment (Fig. S1). In addition to hypha-specific genes, we also monitored the cyclin gene CLB4 and its inhibitor SIC1. CLB4 showed sustained downregulation in both the pph3A and psy2A mutant as compared to wild type cells. In contrast, expression of its inhibitor gene SIC1 was higher in pph3 4 and psy $2 \Delta$ cells than in wild-type cells under normal conditions and increased further after MMS treatment (Fig. 3A), supporting the observation that pph3A and psy $2 \Delta$ cells were unable to recover from cell cycle arrest. However, whether these phenomena are directly related to Rad53 remains to be investigated.

Northern blot (Fig. 3C) and qPGR (Fig. 4D) analyses produced consistent results in the expression levels of MSH2, RFA2, CCN1, $P C L 2$ and HWP1, which are genes involved in either cell cycle regulation or hyphal growth. Among these genes, downregulation of RFA2 in pph3 $\triangle$ and psy $2 \Delta$ mutants after MMS recovery was further confirmed by Western blot analyses (Fig. 4D). Therefore, our results suggest that Rad53 hyperphosphorylation resulting from PPH3 and PSY2 deletion triggers its downstream signaling, which may contribute to MMS sensitivity.

Pph3 and Ptc2 are two phosphatases that have been implicated in Rad53 dephosphorylation during genotoxic stress [28,33,34]. Next, we asked whether RFA2 downregulation during MMS treatment is specific to $P P H 3$ deletion. To this end, we spotted BWP17, pph3 4 , psy2 2 , ptc2 $\Delta$ and pph3 4 ptc2 4 cells onto YPD plates containing different concentrations of MMS or $\mathrm{HU}$, and incubated at $30^{\circ} \mathrm{C}$ for $24 \mathrm{~h}$. Results showed that in the absence of genotoxin, the pph3A, psy $2 \Delta$ and ptc2 $\Delta$ mutant exhibited normal growth indistinguishable from the wild-type strain; however, the 
A
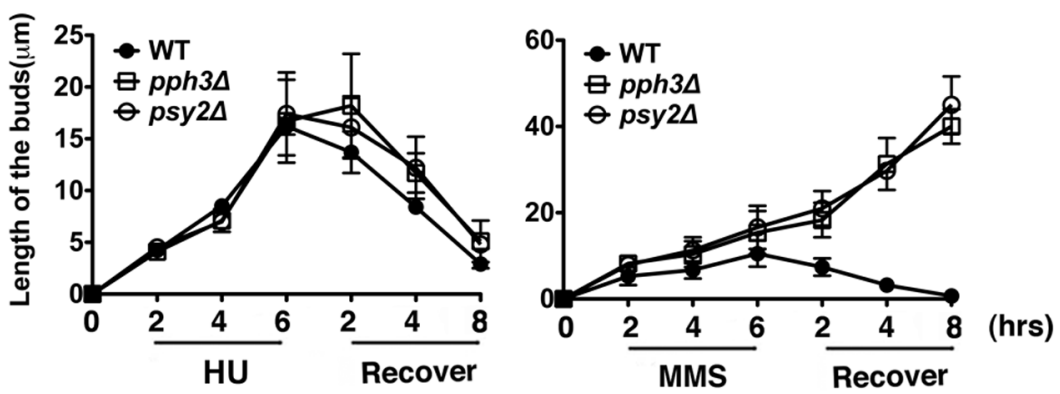

B

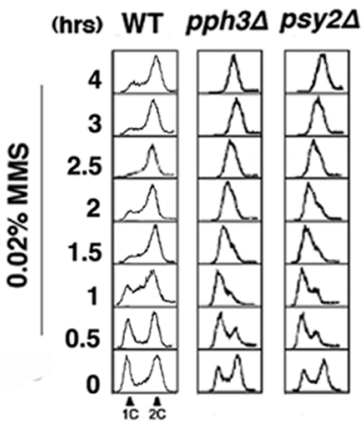

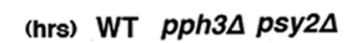

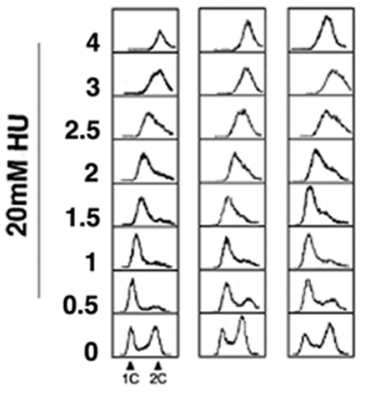

C
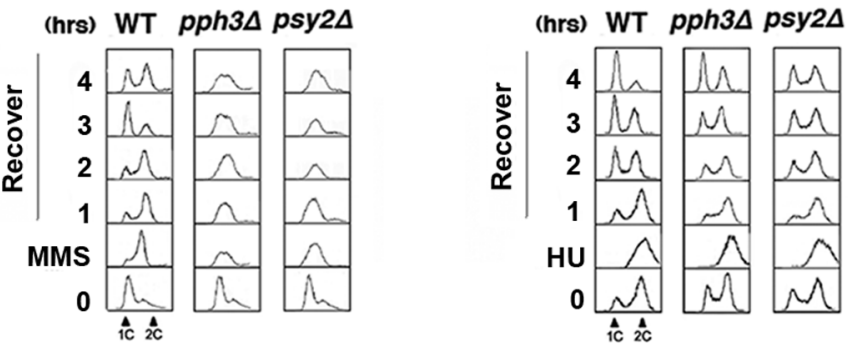

Figure 1. pph3 $\triangle$ and psy2 $\triangle$ cells exhibit pseudohyphal growth and cell cycle arrest when treated with MMS or HU. Fig $1 \mathrm{~A}$. Wild-type (SC5314 or BWP17), pph34 (SJL3) and psy24 (SJL6) cells were grown in liquid YPD medium supplemented with $0.02 \% \mathrm{MMS}$ or $20 \mathrm{mM} \mathrm{HU}$ at $30^{\circ} \mathrm{C}$ for $6 \mathrm{~h}$, washed with fresh YPD and resuspended into fresh YPD for further growth at $30^{\circ} \mathrm{C}$ for $8 \mathrm{~h}$. Bud length was measured using ImageJ (http:// rsbweb.nih.gov/ij/index.html). Each data point represents the average of 30 cells measured in 3 independent experiments. Fig 1B. The same cells as used in (A) were treated with $0.02 \% \mathrm{MMS}$ or $20 \mathrm{mM} \mathrm{HU}$. Cells were harvested at indicated time intervals for flow cytometry analysis. Fig 1C. The same cells as used in (A) were treated with $0.02 \% \mathrm{MMS}$ or $20 \mathrm{mM} \mathrm{HU}$ at $30^{\circ} \mathrm{C}$ for $6 \mathrm{~h}$ and recovered in fresh YPD as described in (A). Cells were harvested at indicated time intervals for flow cytometry analysis.

doi:10.1371/journal.pone.0037246.g001

pph3 4 ptc2 $\Delta$ mutant grew more slowly (Fig. 4A), suggesting some degree of functional redundancy between Pph3 and Ptc2 in cell growth. In the presence of genotoxins, while all mutants showed increased sensitivity, the pph3 4 ptc2 $\Delta$ mutant was the most sensitive (Fig. 4A\&B), indicating that Pph3 and Ptc2 have both independent and redundant functions important for cell viability in response to genotoxic stress. Ptc2 seemed to play a lesser role in MMS sensitivity than Pph3, because the ptc24 mutant displayed lower MMS sensitivity than both the pph3 $\Delta$ and psy2 4 mutant (Fig. 4A\&B). All the single-gene deletion mutants exhibited similar sensitivity to $\mathrm{HU}$ (Fig. 4A\&B). Western blotting of Rfa2-Myc in

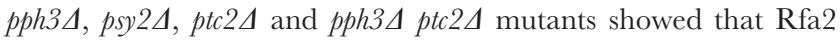
cellular levels were comparable in HU-treated mutant cells (Fig. 4C). In comparison, its cellular level diminished significantly after MMS treatment in pph3 4 , psy2 $\Delta$ and pph3 $\Delta$ tc2 4 mutants, while remained unaffected in wild-type and ptc2 $2 \Delta$ cells (Fig. 4D). Therefore, these results suggest that downregulation of $\mathrm{Rfa} 2$ is closely associated with Pph3 dephosphorylation of Rad53.
Double bands were observed of Rfa2 after HU and MMS treatment (Fig. 4C\&D). Previous studies demonstrated that RPA2, the human homolog of Rfa2, is hyperphosphorylated under various genotoxic stresses [43-48]. Thus, the upper band may represent phosphorylated Rfa2. However, we have not studied the post-translational modification of Rfa2. Nevertheless, this should not compromise our conclusion that $\mathrm{Rfa} 2$ downregulation is a result of $\mathrm{PPH} 3$ deletion.

\section{Identification of potential MMS-related dephosphorylation sites on Rad53}

To identify potential phosphorylation sites on Rad53 that may be responsible for MMS sensitivity, we performed phosphomimetic mutagenesis on previously reported phosphorylation sites (Fig. 5A). Results showed that the Rad53 phosphomimetic mutants of S461D and S545D (corresponding to 489 and 560 in S. cerevisiae, GeneID 855950) exhibited higher sensitivity to MMS but not HU than the wild-type strain (Fig. 5B). Viability of these 
Table 1. C. albicans strains used in this study.

\begin{tabular}{|c|c|c|}
\hline Strains & Relevant genotype & Source \\
\hline SC5314 & Wild type, clinical isolate & \\
\hline BWP17 & ura3/ura3 his1:hisG/his1::hisG arg4::hisG/arg4::hisG & [69] \\
\hline SJL2 & 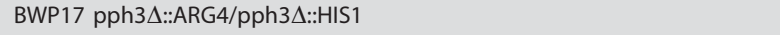 & [36] \\
\hline SJL2.1 & 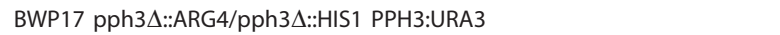 & [36] \\
\hline SJL3 & BWP17 pph3 $\Delta:: A R G 4 / p p h 3 \Delta:: H I S 1$ URA3 & [36] \\
\hline SJL5 & BWP17 psy2 $\Delta:: A R G 4 /$ psy2 $\Delta:: H I S 1$ & [36] \\
\hline SJL5.1 & BWP17 psy2A::ARG4/psy2A::HIS1 PSY2:URA3 & [36] \\
\hline SJL6 & BWP17 psy2A::ARG4/psy2 $\Delta::$ HIS1 URA3 & [36] \\
\hline SJL7 & 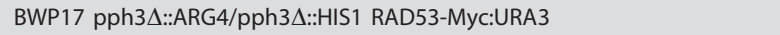 & [36] \\
\hline SJL8 & BWP17 psy2 $\Delta:: A R G 4 / p s y 2 \Delta:: H I S 1$ RAD53-Myc:URA3 & [36] \\
\hline SJL9 & BWP17 RAD53-Myc-URA3 & [36] \\
\hline HKD1 & BWP17 ptc2 $\Delta:: A R G 4 / p t c 2 \Delta:: H I S 1$ & unpublished \\
\hline HKD1.1 & BWP17 ptc2 $\Delta:: A R G 4 / p t c 2 \Delta:: H I S 1$ URA3 & unpublished \\
\hline HKD2 & 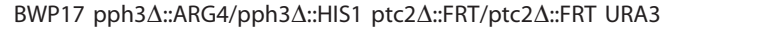 & unpublished \\
\hline HT1 & BWP17 RFA2-Myc-URA3 & This study \\
\hline HT2 & BWP17 pph3 $\Delta::$ ARG4/pph3 $\Delta::$ HIS1 RFA2-Myc:URA3 & This study \\
\hline HT3 & BWP17 psy2A::ARG4/psy2 $\Delta:: H I S 1$ RFA2-Myc:URA3 & This study \\
\hline HT4 & BWP17 ptc2 $\Delta:: A R G 4 / p t c 2 \Delta:: H I S 1$ RFA2-Myc:URA3 & This study \\
\hline HT5 & 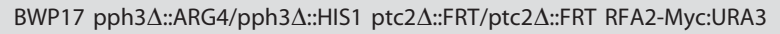 & This study \\
\hline WY3 & $\operatorname{rad} 53 \Delta::$ ARG4/rad53 $\Delta::$ URA3 & [19] \\
\hline HT6 & 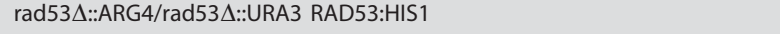 & This study \\
\hline HT7 & 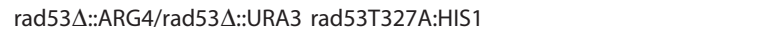 & This study \\
\hline HT8 & $\operatorname{rad} 53 \Delta::$ ARG4/rad53 $\Delta::$ URA3 $\operatorname{rad53T327D:HIS1~}$ & This study \\
\hline HT9 & $\operatorname{rad} 53 \Delta::$ ARG4/rad53 $\Delta::$ URA3 $\operatorname{rad53S350A:HIS1~}$ & This study \\
\hline HT10 & 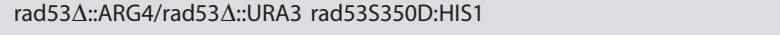 & This study \\
\hline HT11 & $\operatorname{rad} 53 \Delta::$ ARG4/rad53 & This study \\
\hline HT12 & 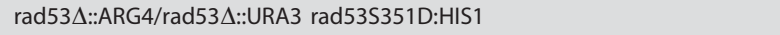 & This study \\
\hline HT13 & $\operatorname{rad} 53 \Delta::$ ARG4/rad53 $\Delta::$ URA3 $\operatorname{rad53S461A:HIS1~}$ & This study \\
\hline HT13.1 & 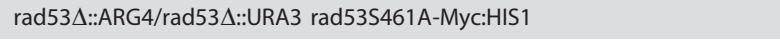 & This study \\
\hline HT14 & 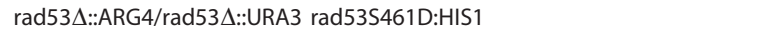 & This study \\
\hline HT14.1 & 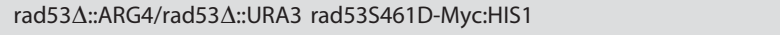 & This study \\
\hline HT15 & $\operatorname{rad} 53 \Delta \because:$ ARG4/rad53 $\Delta::$ URA3 $\operatorname{rad53S545A:HIS1~}$ & This study \\
\hline HT15.1 & 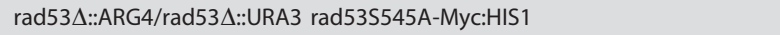 & This study \\
\hline HT16 & $\operatorname{rad} 53 \Delta::$ ARG4/rad53 $\triangle::$ URA3 $\operatorname{rad53S545D:HIS1~}$ & This study \\
\hline HT16.1 & $\operatorname{rad} 53 \Delta::$ ARG4/rad53 $\Delta::$ URA3 rad53S545D-Myc:HIS1 & This study \\
\hline HT17 & 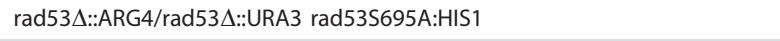 & This study \\
\hline HT18 & 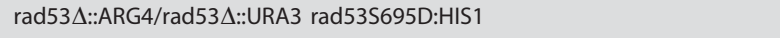 & This study \\
\hline HT19 & $\operatorname{rad} 53 \Delta \because: \mathrm{ARG} 4 / \mathrm{rad} 53 \Delta::$ URA3 $\mathrm{rad} 53 \mathrm{~S} 455 \mathrm{~A} / \mathrm{S} 457 \mathrm{~A} / \mathrm{S} 459 \mathrm{~A} / \mathrm{S} 461 \mathrm{~A}: \mathrm{HIS1}$ & This study \\
\hline HT2O & $\operatorname{rad} 53 \Delta:: \mathrm{ARG} 4 / \mathrm{rad} 53 \Delta::$ URA3 $\mathrm{rad} 535455 \mathrm{D} / \mathrm{S457D/S459D/S461 \textrm {D } : H I S 1}$ & This study \\
\hline HT21 & $\operatorname{rad} 53 \Delta::$ :ARG4/rad53 $\Delta:: F R T$ rad53S461A:HIS1 RFA2-Myc:URA3 & This study \\
\hline HT22 & 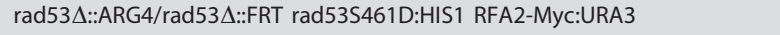 & This study \\
\hline HT23 & $\operatorname{rad} 53 \Delta::$ ARG4/rad53 $\Delta:: F R T$ rad53S545A:HIS1 RFA2-Myc:URA3 & This study \\
\hline HT24 & $\operatorname{rad} 53 \Delta::$ ARG4/rad53 $\Delta:: F R T$ rad53S545D:HIS1 RFA2-Myc:URA3 & This study \\
\hline
\end{tabular}

mutants also dropped dramatically after MMS treatment, but they were able to recover from HU treatment (Fig. 5C, Table 2). Moreover, the two mutants remained in pseudohyphal form $10 \mathrm{~h}$ after MMS withdrawal, but could fully return to the yeast growth after HU treatment (Fig. 5D, Table 2).
On the other hand, the Rad53-S351D mutant (corresponding to $\mathrm{S} 375$ in S. cerevisiae Rad53p) exhibited higher sensitivity to both HU and MMS as compared to wild-type and the Rad53-S461D and Rad53-S545D mutants (Fig. 5B). However, it could partially recover from both HU and MMS treatment (Table 2), suggesting 
A

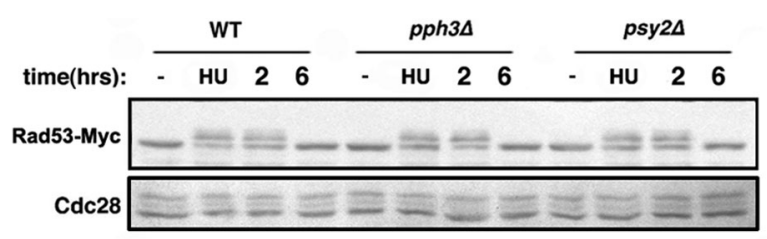

B

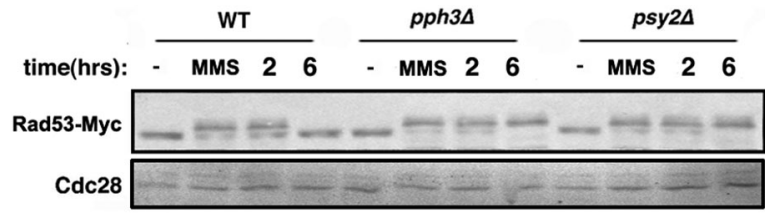

Figure 2. Rad53 undergoes hyperphosphorylation in response to $\mathrm{HU}$ and MMS. Fig 2A. Rad53 hyperphosphorylation in HU-treated cells. SJL9 (wild type with RAD53-Myc), SJL7 (pph3A RAD53-Myc), and SJL8 (psy2 $\triangle$ RAD53-Myc) cells were incubated at $30^{\circ} \mathrm{C}$ in YPD containing $20 \mathrm{mM}$ HU for $4 \mathrm{~h}$. Cells were then washed and recovered with fresh YPD for the indicated times. Whole cell lysates were used for immunoblot analysis with anti-Myc antibody. Untreated cells were used as control. Cdc28 was probed with anti-PSTAIRE antibody as loading control. Fig 2B. Rad53 hyperphosphorylation in MMS-treated cells. SJL9 (wild type with RAD53-Myc), SJL7 (pph3A RAD53-Myc), and SJL8 ( $p s y 2 \triangle$ RAD53-Myc) cells were incubated at $30^{\circ} \mathrm{C}$ in YPD containing $0.02 \%$ MMS for $4 \mathrm{~h}$. Cells were then washed and recovered with fresh YPD for the indicated times. Whole cell lysates were used for immunoblot analysis with anti-Myc antibody. Untreated cells were used as control. Cdc28 was probed with anti-PSTAIRE antibody as loading control.

doi:10.1371/journal.pone.0037246.g002

that S351 is less important in determining MMS sensitivity than S461 and S545. Furthermore, the stronger phenotype of the S to D mutation at the residues of S351, S461 and S545 suggests that phosphorylation at these sites potentially affects kinase function. Therefore, we conclude that phosphorylation at S461 and S545 appears to have a more important role in determining MMS sensitivity.

To gain evidence that phosphorylation at the above residues on Rad53 is biologically relevant, we first confirmed that the $\mathrm{S}$ to $\mathrm{D}$ mutants resulted in sustained Rad53 hyperphosphorylation after MMS treatment and recovery (Fig. 6A) but not HU (Fig. S4). Next, we used qPCR to examine the expression of Rad53 downstream genes after MMS treatment and recovery. qPGR results showed that RFA2 as well as the cyclin genes of CCN1 and PCL2 were downregulated in both Rad53-S461D and Rad53S545D mutants after MMS treatment and during the recovery, while there was no obvious difference between the Rad53-S461A and Rad53-S545A mutants and the wild type (Fig. 6B). Western blotting analysis revealed that $\mathrm{Rfa} 2$ levels were not recovered in the Rad53-S461D and Rad53-S545D mutants, similar to results obtained in the pph3 $\Delta$ mutant (Fig. 6C). Hence, our results strongly suggest that failure of dephosphorylation at S461 and S545 on Rad53 may be responsible for the MMS-induced pseudohyphal growth and sensitivity in pph34 and psy 24 mutants.

\section{Discussion}

We have previously shown that $\mathrm{Pph} 3$ and its regulatory subunit Psy2 are required for recovery from MMS and cisplatin treatment in C. albicans [38]. Here, we demonstrated that pph3 $\Delta$ and $p s y 2 \Delta$ mutants exhibited hypersensitivity to MMS but not HU, consistent with earlier discoveries in S. cerevisiae [34]. Moreover, our results demonstrate that such hypersensitivity is closely related to CaRad53 hyperphosphorylation and that Pph3/Psy2 plays a pivotal role. Consistent with our results, Bazzi, et al. [49] showed that Glc7 but not Pph3 promoted disappearance of hyperphosphorylated Rad53 and cell's recovery after HU treatment.

Hyperphosphosphorylation of CaRad53 was observed in our pph3 $\Delta$ and psy $2 \Delta$ mutants upon MMS treatment. Rad53 is the yeast homolog of the mammalian tumor suppressor Chk2. It is an important checkpoint kinase that is activated in response to genotoxic stress and deactivated upon stress removal in order to exit from cell cycle arrest [23]. Rad53 deactivation is achieved through its dephosphorylation by various phosphatatases including the human PP4 homolog of Pph3, the human PP2C homologs of Ptc2 and Ptc3 [28], and the human PP1 homolog of Glc7 [49]. A large body of evidence demonstrated that different phosphorylation patterns prevail on Rad53 under different genotoxic stresses. This is regulated by different activities of various kinases and phosphatases, some of which may be redundant. For instance, $p p h 3 \Delta$ cells are hypersensitive to phleomycin, while ptc2 $\Delta$, ptc3 $\Delta$ and ptc $2 \Delta$ ptc $3 \Delta$ cells are not; on the contrary, ptc $2 \Delta$ ptc $3 \Delta$ cells are hypersensitive to 4-NQO while pph3 $\Delta$ mutants are not [35]. Alternatively, Glc7, but not Ptc2, Ptc3 or Pph3, is required for recovery from an $\mathrm{HU}$-induced checkpoint, while it is dispensable for checkpoint inactivation during MMS exposure. Here, we observed that the pph $3 \Delta$ ptc $2 \Delta$ double $\mathrm{KO}$ mutant exhibited higher sensitivity to MMS than the pph3 $\Delta$ mutant, suggesting a possible role for Ptc2 in MMS sensitivity in C. albicans. Hence, a consensus is that different signaling pathways are activated in response to different genotoxic stresses, leading to different phosphorylation patterns of Rad53 and activation of different downstream signaling pathways.

Swi6 is a substrate of Rad53 and controls the G1/S cell cycle checkpoint. It interacts with Swi4 in the SBF complex associates with Mbpl in the MBF complex in S. cerevisiae [50-54]. The SBF/ $\mathrm{MBF}$ complexes are regulated through phosphorylation of Swi6 by Rad53. In S. cerevisiae, Rad53-dependent phosphorylation of Swi6 delayed the transition to $\mathrm{S}$ phase, possibly by inhibiting $C L N$ transcription [46]. In C. albicans, cells lacking Swi4 and Swi6 demonstrated pronounced downregulation of the G1 cyclin genes CCN1 and PCL2 [55]. We observed a similar scenario of downregulation of MBF-regulated genes in the pph3 $\Delta$ mutant upon MMS treatment. In addition, RFA2 downregulation was only observed in the pph3 $\Delta$ mutant but not in the ptc2 $\Delta$ mutant upon MMS treatment, providing evidence for a Pph3-mediated dephosphorylation event specific for regulating the transcription of one, if not all, Swi6-regulated genes. Therefore, we deduce that such phenomenon results from the dysregulation of Pph3-dependent dephosphorylation of CaRad53.

Furthermore, downregulation of Rfa2 might also contribute to the pseudohyphal phenotype in the pph $3 \Delta$ mutant upon MMS treatment in addition to the downregulation of SBF/MBF genes. $\mathrm{Rfa} 2$ is a conserved single strand DNA (ssDNA) binding protein that forms a heterotrimeric complex with two other subunits Rfal and Rfa3 to stabilize ssDNA during DNA replication, repair and recombination [56,57]. RFA2 mutations were demonstrated to induce $\mathrm{S}$ phase arrest in $S$. cerevisiae [58]. Here, we demonstrated that Rfa2 was downregulated upon Rad53 hyperphosphorylation in pph3 $\Delta$ mutant. Thus, it is likely that changes in Rfa2 cellular levels contribute to the hyphal growth of $C$. albicans in addition to the downregulation of SBF/MBF genes.

Numerous studies have investigated the phosphorylation status of Rad53 under different genotoxic stresses [32,59-62]. Different 


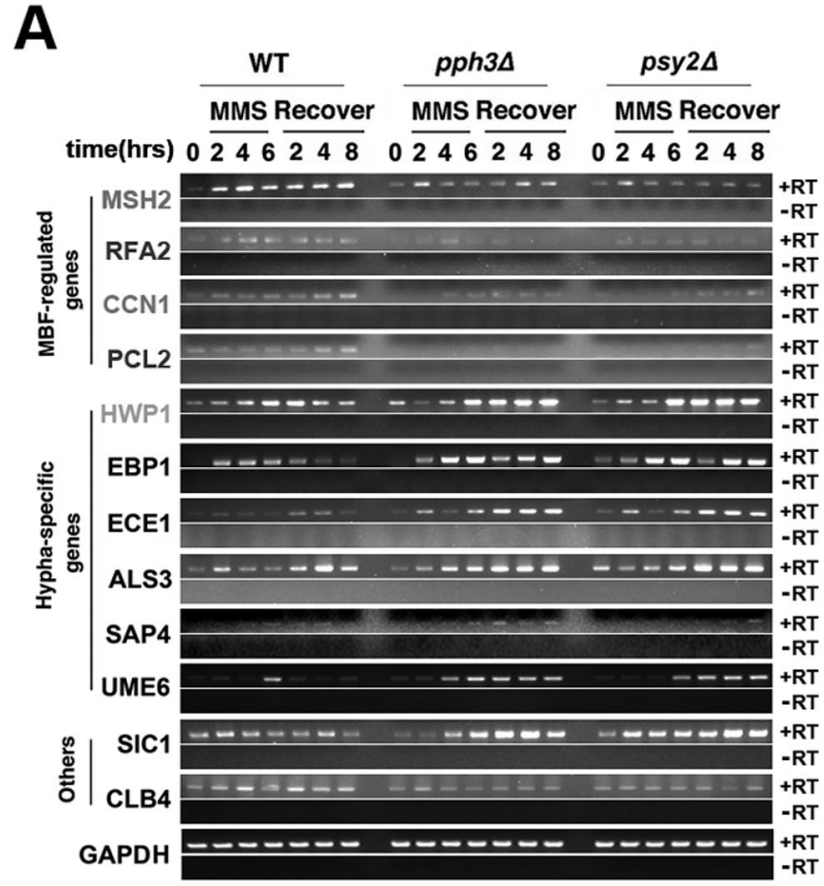

B
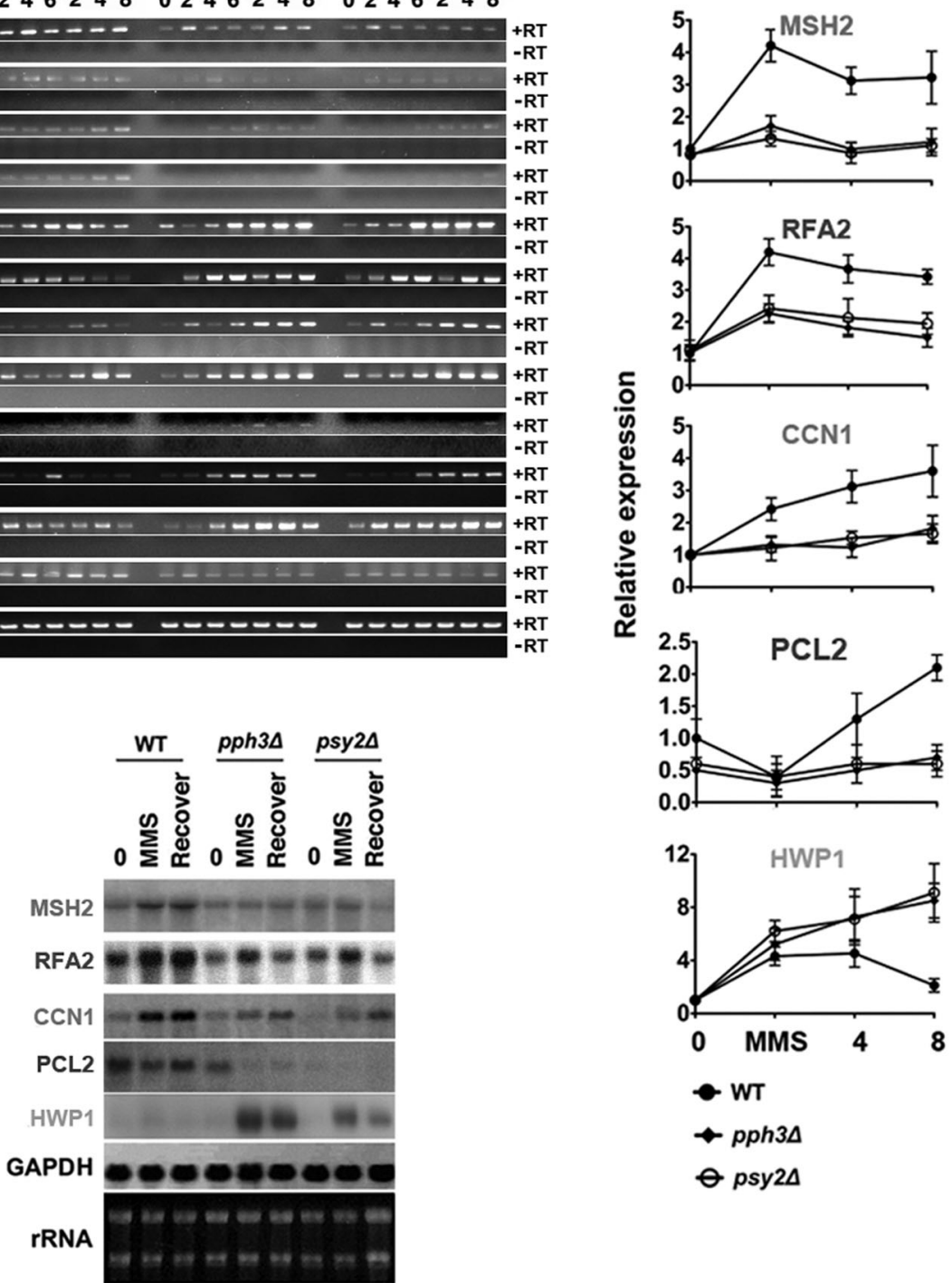

Figure 3. Detection of Rad53 downstream signalling by RT-PCR, Northern blot and qPCR in pph $3 \Delta$ and psy $2 \Delta$ cells. Fig $3 \mathrm{~A}$. Wild-type (S5314 or BWP17), pph34 (SJL3) and psy2 4 (SJL6) cells were incubated at $30^{\circ} \mathrm{C}$ in YPD containing $0.02 \% \mathrm{MMS}$ and then recovered with fresh YPD over the indicated time period. RNA extracted from harvested cells at indicated time points was used for RT-PCR analysis. PCR amplifications in absence of retrotranscriptase for each sample was used as negative controls in RT-PCR. GAPDH was used as loading control. Fig 3B. Wild-type (S5314 or BWP17), pph3 4 (SJL3) and psy2 2 (SJL6) cells were incubated at $30^{\circ} \mathrm{C}$ in YPD containing $0.02 \%$ MMS for $6 \mathrm{~h}$ and then recovered with fresh YPD for $6 \mathrm{~h}$. RNA was extracted and subject to Northern blot analysis. GAPDH was used as control and rRNA was shown to indicate RNA integrity. Fig 3C. Wild-type (S5314 or BWP17), pph3 4 (SJL3) and psy2 $\Delta$ (SJL6) cells were incubated at $30^{\circ} \mathrm{C}$ in YPD containing $0.02 \% \mathrm{MMS}$ for $6 \mathrm{~h}$ and then recovered with fresh YPD over the indicated time period. RNA was extracted and reverse transcribed into CDNA at the indicated time points for qPCR analysis. All data represent the mean of 3 independent experiments. doi:10.1371/journal.pone.0037246.g003

phosphorylation sites on Rad53 have been mapped by mass spectrometry analysis after MMS, HU and 4-NQO treatment $[32,59]$. Based on these results together with sequence alignment, we mutated Thr327, Ser350, Ser351, Ser461, Ser545 and Ser695 in C. albicans Rad53 which correspond to Ser350, Ser373, Ser375, Ser489, Ser560 and Ser747 in S. cerevisiae Rad53 respectively. We observed that the S461D and S545D single amino-acid mutants (Figure 5, Table 2), and the S455D/S457D/S459D/S461D quadruple mutant (Table 2), which are located in the G-terminal
SCD (SQ Cluster Domain), displayed stronger phenotypes than their S to A counterparts upon MMS treatment. Sweeney [63] provided evidence that a truncated fragment of ScRad53 (aal70512) containing S485E/S489E mutations (corresponding to CaRad53-S457E/S461E) elevated ScRad53 trans-autophosphorylation activity in vitro. These data suggest that the C-terminal SCD might confer MMS hypersensitivity in C. albicans via transautophosphorylation of CaRad53. In support of this hypothesis, we observed that strains expressing the CaRad53-S461D and 
A

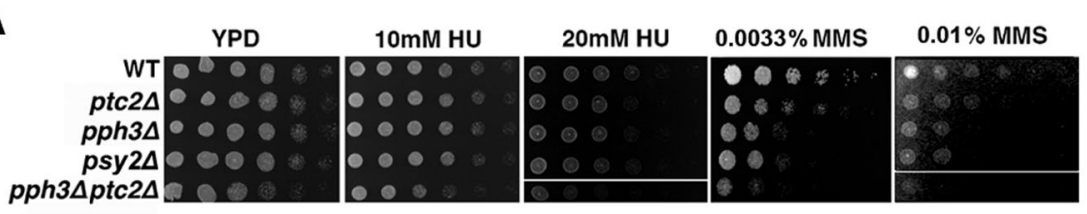

B

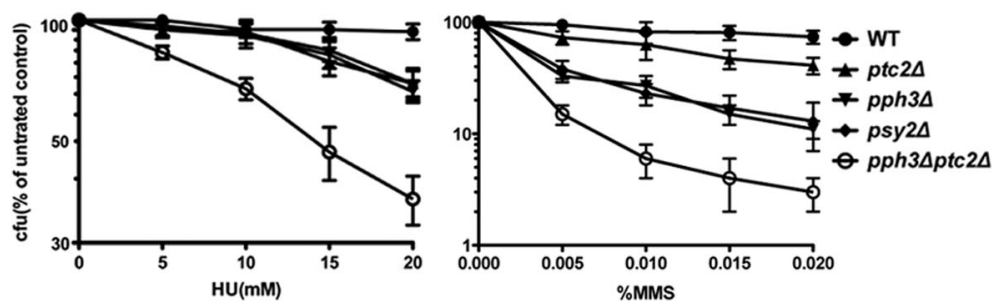

C

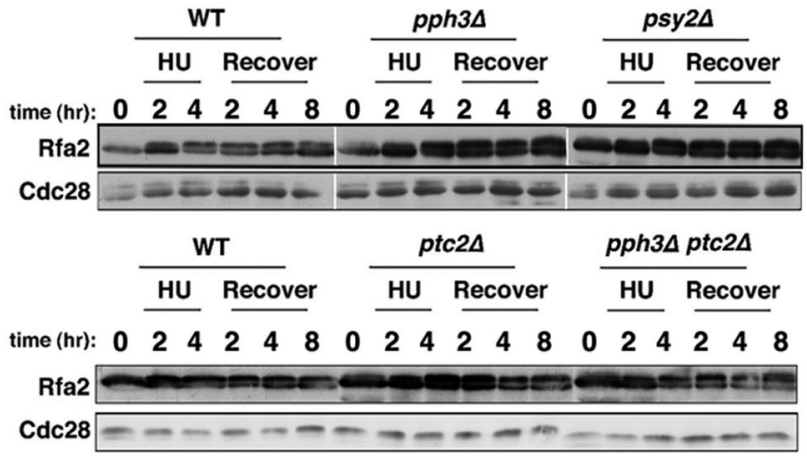

D

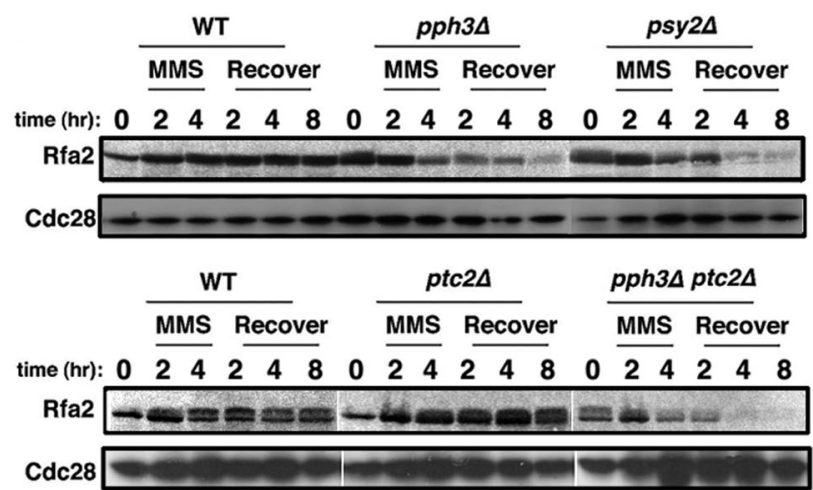

Figure 4. Rfa2 was downregulated in pph $3 \Delta$ and pph3 3 ptc2 $\triangle$ mutant upon MMS but not HU treatment. Fig 4A. Wild-type (HT1), pph3 $\triangle$ (HT2), psy2 4 (HT3), ptc2 4 (HT4) and pph34 ptc2 $\Delta$ (HT5) cells were 10-fold serially diluted, spotted onto YPD plates containing different concentrations of $\mathrm{HU}$ or MMS, and incubated at $30^{\circ} \mathrm{C}$ for $24 \mathrm{~h}$. Fig 4B. Approximately equal numbers of yeast cells were spread onto YPD plates containing different concentrations of $\mathrm{HU}$ and MMS for incubation at $30^{\circ} \mathrm{C}$ for $2 \mathrm{~d}$. Percentage of viability was expressed as colony-forming units (CFU) of HU- or MMStreated mutants compared to untreated wild-type control. Fig 4C. Wild-type (HT1), pph34 (HT2), psy2 4 (HT3), ptc2 4 (HT4) and pph34 ptc2 4 (HT5) cells expressing C-terminally Myc-tagged Rfa2 were incubated at $30^{\circ} \mathrm{C}$ in YPD containing $20 \mathrm{mM} \mathrm{HU}$ and recovered with fresh YPD over the indicated time period. Untreated cells was used as control. Total protein was extracted from harvested cells at the indicated time points and subject to immunoblot analysis with anti-Myc antibody. Cdc28 was probed with anti-PSTAIRE antibody as loading control. Fig 4D. Wild-type (HT1), pph34 (HT2), psy2 24 (HT3), ptc2 2 (HT4) and pph3 4 ptc2 $\triangle$ (HT5) cells expressing C-terminally Myc-tagged Rfa2 were incubated at $30^{\circ} \mathrm{C}$ in YPD containing $0.02 \%$ MMS and recovered with fresh YPD over the indicated time period. Untreated cells were used as control. Total protein was extracted from harvested cells at the indicated time points and subject to immunoblot analysis with anti-Myc antibody. Cdc28 was probed with anti-PSTAIRE antibody as loading control.

doi:10.1371/journal.pone.0037246.g004

CaRad53-S545D proteins became hyperphosphorylated after MMS treatment in vivo but behaved similarly as the wild-type protein in unperturbed conditions (Fig. 6A). Thus, we believe that CaRad53 S461 and S545 contribute to but are not fully responsible for activating the kinase activity. Additional factors and/or pathways must be involved which need to be further investigated.
Earlier studies demonstrated that Psy2 binds to the kinase domain of Rad53 in S. cerevisiae [34]. Based on published mass spectrometry results [32,59-63], Ser351 is phosphorylated upon MMS treatment. Therefore, we performed viability assays using the CaRad53-S351 mutants. Both S351D and S351A mutants exhibited lower viability upon MMS treatment, with the $\mathrm{S}$ to $\mathrm{D}$ mutant exhibiting a slightly stronger phenotype. We thus deduce 


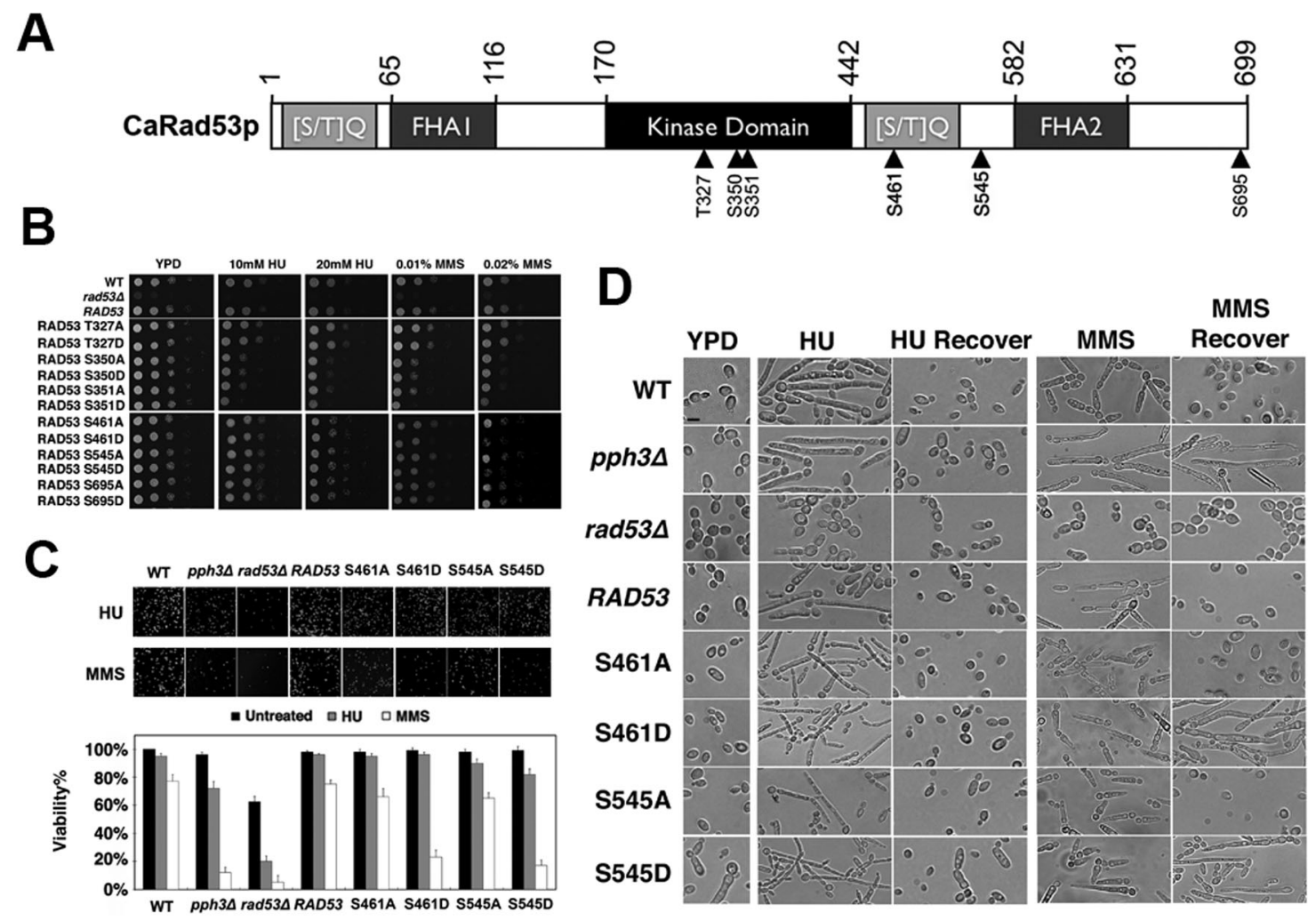

Figure 5. Viability assays of Rad53 phosphomimic mutants upon MMS and HU treatment. Fig 5A. Domain organizations of $C$. albicans Rad53 and S. cerevisiae Rad53. Arrowheads mark [S/T]Q amino acid mutant site. Amino acids at domain boundaries are indicated by numbers. Schematic description of the strategy for integrating RAD53 wild-type and mutant alleles at the RAD53 chromosomal locus (for details, see Materials and Methods.). Fig 5B. Cells of wild-type (S5314 or BWP17), rad534 (WY3), the rescued RAD53 (HT6) and the various strains expressing mutant alleles of RAD53 (HT7-18 refer to Table 1) were 10-fold serially diluted, spotted onto YPD plates containing different concentrations of HU or MMS, and incubated at $30^{\circ} \mathrm{C}$ for $24 \mathrm{~h}$. Fig $5 \mathrm{C}$. Approximately equal numbers of cells of wild type (S5314 or BWP17), pph3A (SJL3), rad534 (WY3), the rescued RAD53 (HT6) and the various strains expressing mutant alleles of RAD53 (HT13-16 rad53-S461A, rad53-S461D, rad53-S545A, rad53-S545D) were treated with $20 \mathrm{mM} \mathrm{HU}$ or $0.02 \mathrm{mM}$ for $2 \mathrm{~h}$ in liquid culture and then spread onto YPD plates for incubation at $30^{\circ} \mathrm{C}$ for $2 \mathrm{~d}$. Percentage of viability was expressed as CFU of the untreated mutants compared to untreated wild-type cells, and CFU of HU-treated or MMS-treated mutants was compared to their untreated counterpart. All data show the average of three independent experiments with error bars. Fig 5D. Cells of wild type (S5314 or BWP17), pph34 (SJL3), rad53 (WY3), the rescued RAD53 (HT6) and the various strains expressing mutant alleles of RAD53 (HT13-16 rad53-S461A, rad53-S461D, rad53-S545A, rad53-S545D) were grown in liquid YPD medium supplemented with $0.02 \% \mathrm{MMS}$ or $20 \mathrm{mM} \mathrm{HU}$ at $30^{\circ} \mathrm{C}$ for $4 \mathrm{~h}$. Cells were collected for microscopic examination. $0.02 \%$ MMS or $20 \mathrm{mM}$ HU treated cells washed with fresh YPD and recovered into MMS-free and $\mathrm{HU}$-free $\mathrm{YPD}$ at $30^{\circ} \mathrm{C}$ for $8 \mathrm{~h}$. Cells were collected for microscopic examination. (Bar $=5 \mu \mathrm{m})$ doi:10.1371/journal.pone.0037246.g005

that this mutation might have altered the kinase activity due to its location in the activation loop of the Rad53 kinase. Hence, we propose that S461 and S545 have a more important role in determining MMS sensitivity in C. albicans.

Sequence alignment of ScRad53 and CaRad53 to their human homolog Chk2 revealed that the C-terminal SCD is unique to the yeast proteins, while the $\mathrm{N}$-terminal SCD is present in yeast Rad53 and human Chk2. Phosphorylation of the SCDs is closely associated with protein function and cell viability. For instance, phosphorylation at ScRad53-T354 and ScRad53-T358 in the activation loop is required for kinase activity [64-66]. Transphosphorylation of the ScRad53 N-terminal SCD is crucial for interaction with Dunl, the complex of which is involved in G2/M checkpoint [67]. Chk2-T68 phosphorylation is dependent on ATM/ATR and triggers Chk2 oligomerization, which led to PIKK-independent kinase activation [66,68]. Furthermore, transphosphorylation at ScRad53-S485 and ScRad53-S489 by Mec1 and Tell kinases was shown to affect Rad53 oligomerization [63,69]. Phosphorylation of this region is critical for protein function and hence cell viability $[67,69]$. Thus, our finding of S461 in this region of CaRad53 as a potential site for phosphoregulation of cell's sensitivity to MMS may be explored as targets for developing for specific therapeutics to treat C. albicans infections.

\section{Materials and Methods}

Strains and culture conditions

All C. albicans strains used in this study are listed in Table 1. Except where noted. C. albicans were routinely grown at $30^{\circ} \mathrm{C}$ in YPD medium ( $2 \%$ yeast extract, $1 \%$ peptone, and $2 \%$ glucose), in GMM $(2 \%$ glucose and $6.79 \mathrm{~g} / \mathrm{L}$ yeast nitrogen base without amino acids), or in GMM supplemented with the required nutrients for auxotrophic mutants. Solid media contained $2 \%$ agar.

\section{Test of sensitivity to DNA damaging agents}

Sensitivity to DNA-damaging agents was tested on solid or in liquid medium. For growth on solid media, cells were first grown in liquid YPD overnight at $30^{\circ} \mathrm{C}$ and 10 -fold serially diluted with fresh YPD to concentrations of $1 \times 10^{2}$ to $1 \times 10^{7}$ cells $/ \mathrm{mL}$; after 
Table 2. Effects of the Rad53 S/T mutations on DNA checkpoint-mediated function.

\begin{tabular}{|c|c|c|c|c|c|c|}
\hline & \multicolumn{2}{|c|}{ Elongated cell ${ }^{\mathbf{a}}(\%)$} & \multicolumn{2}{|c|}{ Elongated cell after recovery ${ }^{a}(\%)$} & \multicolumn{2}{|c|}{ Recovery rate $^{\text {b }}$} \\
\hline & HU & MMS & HU & MMS & HU & MMS \\
\hline WT & 95 & 83 & 4 & 10 & +++++ & +++++ \\
\hline pph34 & 97 & 98 & 12 & $99^{*}$ & h+r+ & $+^{*}$ \\
\hline $\operatorname{rad534}$ & 2 & 1 & 1 & 1 & + & + \\
\hline RAD53 & 93 & 82 & 3 & 12 & H+H & +r+t+ \\
\hline rad53-Т327A & 92 & 85 & 9 & 11 & +r+H & +++++ \\
\hline rad53-S350A & 91 & 88 & 5 & 8 & $h++1+$ & H+H \\
\hline rad53-S351A & 93 & 90 & 9 & 16 & +++H & ++++ \\
\hline rad53-S461A & 90 & 92 & 5 & 9 & H+H & +++1+ \\
\hline rad53-S545A & 93 & 91 & 8 & 12 & +++r+ & +++++ \\
\hline rad53-S695A & 93 & 89 & 21 & 23 & H+H & +++++ \\
\hline 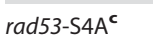 & 95 & 94 & 8 & 15 & +++++ & +++++ \\
\hline rad53-T327D & 93 & 88 & 8 & 18 & H+H+ & ++++ \\
\hline rad53-S350D & 93 & 90 & 9 & 15 & +++H+ & ++++ \\
\hline rad53-S351D & 91 & 89 & 14 & 40 & ++r+ & +++ \\
\hline rad53-S461D & 93 & 95 & 10 & $93^{*}$ & +++++ & $++^{* *}$ \\
\hline rad53-S545D & 98 & 99 & 32 & $90^{*}$ & H+H+ & $++^{* *}$ \\
\hline rad53-S695D & 91 & 94 & 18 & 22 & +++H & +++++ \\
\hline rad53-S4DC & 93 & 95 & 14 & $95^{*}$ & H+H & $H^{* *}$ \\
\hline \multicolumn{7}{|c|}{$\begin{array}{l}\text { a) Stationary-phase yeast cells were treated with } 20 \mathrm{mM} \mathrm{HU} \text { or } 0.02 \mathrm{mM} \text { MMS in fresh YPD for } 6 \mathrm{~h} \text {, recover in fresh YPD for } 8 \mathrm{~h} \text { and the fractions of cells with an } \\
\text { elongated bud (length of bud } 1.5 \text { times that of the mother) were counted. } \\
\text { b) Equivalent numbers of yeast cells were treated with } 20 \mathrm{mM} \text { HU or } 0.02 \mathrm{mM} \mathrm{MMS} \text { for } 2 \mathrm{~h} \text { and then same cell diluted before being spread onto YPD plates for counting } \\
\text { colony-forming units from few (+) to many (+++++) after a 2-d incubation at } 30^{\circ} \mathrm{C} \text {. Indicates * } P \text { value }<0.01 ; * * \text { value }<0.05 \text { compared with values from the control WT } \\
\text { cells. } \\
\text { c) rad53-S4A mean a quadruple mutant of S455A/S457A/S459A/S461A; rad53-S4D mean a a quadruple mutant of S455D/S457D/S459D/S461D. } \\
\text { doi:10.1371/journal.pone.0037246.t002 }\end{array}$} \\
\hline
\end{tabular}

$2 \mathrm{~h}$ of growth at $30^{\circ} \mathrm{C}, 2 \mu \mathrm{L}$ of each culture was plated onto YPD plates containing different concentrations of $\mathrm{HU}$ or MMS and the plates were photographed after $24 \mathrm{~h}$ incubation at $30^{\circ} \mathrm{C}$. For liquid cultures, cells were grown in YPD at $30^{\circ} \mathrm{C}$ overnight and diluted with fresh YPD medium to a concentration of $5 \times 10^{6}$ cells/ $\mathrm{mL}$. After $2 \mathrm{~h}$ incubation at $30^{\circ} \mathrm{C}$, MMS or $\mathrm{HU}$ was added to a final concentration of $0.02 \%$ or $20 \mathrm{mM}$, respectively, and further incubated for $2-12 \mathrm{~h}$ before the cells were harvested.

For DNA damage recovery experiments, harvested cells were washed twice with distilled water after drug treatment, and resuspended in fresh YPD medium for further growth. For cell recovery rate assays, aliquots of $1 \times 10^{3}$ cells $/ \mathrm{mL}$ starting culture were collected at timed intervals after drug treatment and spread onto YPD plates where colony-forming units were counted after $1-2 \mathrm{~d}$ of incubation at $30^{\circ} \mathrm{C}$.

\section{Construction of C. albicans mutant strains}

C. albicans homologs of corresponding S. cerevisiae genes were identified in the C. albicans genome (http://www.candidagenome. org) by sequence alignment. C. albicans deletion mutants were constructed by sequentially deleting the two copies of the target gene(s) with two deletion cassettes from the wild-type strain of BWP17 [70,71]. The two deletion cassettes were constructed by flanking a selectable marker gene (ARG4 or HISI) with the $\mathrm{AB}$ and CD DNA fragments $\left(\sim 400 \mathrm{bp}\right.$ each), that correspond to the $5^{\prime}$ and $3^{\prime}$ untranslated regions (UTRs) of the target gene, respectively $[21,38]$. Homozygous deletion mutants were verified by PCR.

For rescue experiments, the entire open reading frame (ORF) of the target gene, together with its promoter $(-1,000 \mathrm{bp})$, was cloned into the CIp10-based, URA3-marked plasmid at KpnI and ClaI sites, followed by the GAL4 3' UTR. The construct was linearized by StuI, whose site exists in the RP10 sequence of CIp10, and finally introduced into the gene deletion strains [21].

Construction of PPH3 and PSY2 deletion mutants carrying Cterminal Myc-tagged Rad53 was carried out as previously described [38].

To integrate C-terminal Myc-tagged Rfa2 into mutant strains of various mutation alleles of RAD53, we used the URA3 flipper strategy described previously [72]. First, one copy of RAD53 was replaced with $A R G 4$ as described above. Next, the coding sequence of the second copy of RAD53 was deleted using a URA3 flipper cassette, which was constructed by flanking the 4.2-kb URA3 flipper with the $\mathrm{AB}$ and $\mathrm{CD}$ DNA fragments corresponding to the $5^{\prime}$ and $3^{\prime}$ UTR of target gene. 5-FOA was then applied to delete the URA3 flipper cassette constructs. Then, different mutation alleles of RAD53 were integrated using HIS1 marker. Finally, Gterminal Myc-tagged Rfa2 cloned in CIp10-based, URA3-marked plasmid was linearized at a unique NsiI site, and transformed into different RAD53 mutant strains described in the following context. Similar procedures were taken for double mutation.

Site-directed mutagenesis of RAD53 was performed using the QuickChange Site-Directed Mutagenesis Kit (Stratagene, La Jolla, CA). Primers used in this study are listed in Table S1.

\section{Protein extraction, Western blotting and protein dephosphorylation}

To extract proteins, cells were harvested by centrifugation, and $\sim 100 \mathrm{mg}$ of cell pellet was resuspended in $300 \mu \mathrm{l}$ of ice-cold RIPA 
A

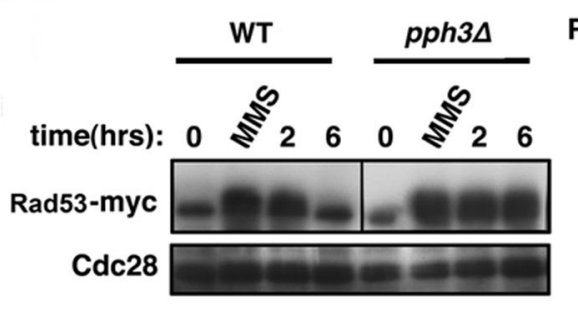

Rad53-S461A Rad53-S461D

Rad53-S545A Rad53-S545D

B
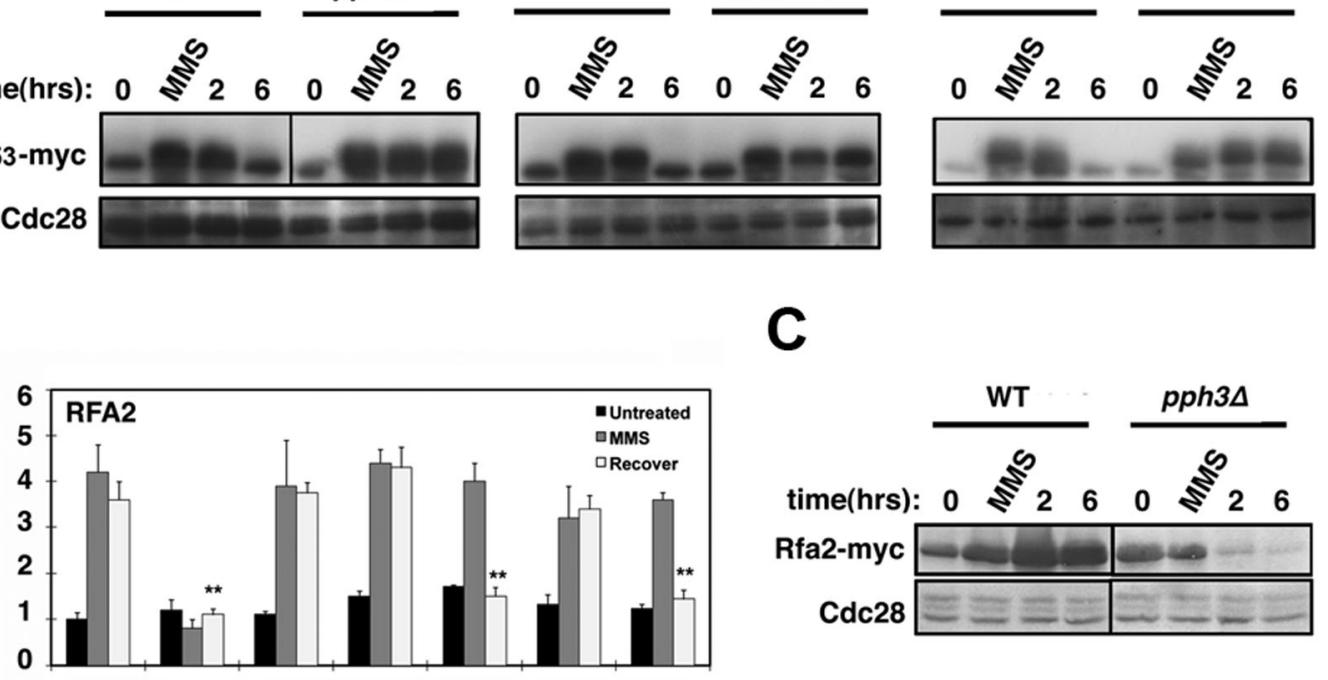

C
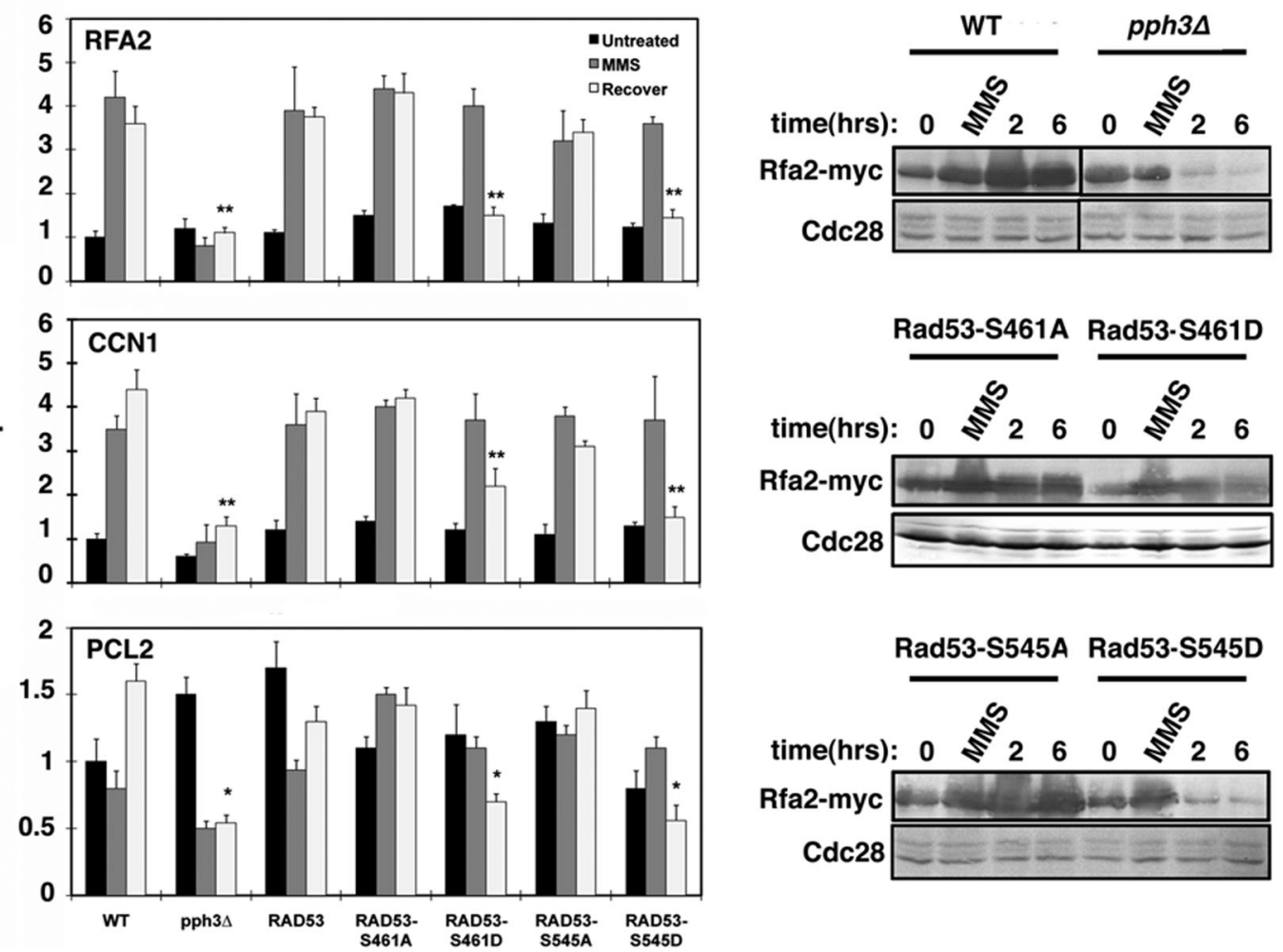

Figure 6. Detection of Rad53 downstream signaling by qPCR and Western blotting in pph $3 \Delta$ cells and cells expressing various mutant alleles of RAD53 upon MMS treatment. Fig 6A. Wild-type (SJL9), pph3A (SJL7), and the various strains expressing C-terminally Myctagged mutant alleles of RAD53 (HT13.1-16.1 rad53-S461A, rad53-S461D, rad53-S545A, rad53-S545D cells were incubated at $30^{\circ} \mathrm{C}$ in $\mathrm{YPD}$ containing $0.02 \%$ MMS for $4 \mathrm{~h}$, then washed and recovered with fresh YPD for the indicated times. Whole cell lysates were used for immunoblot analysis with anti-Myc antibody. Untreated cells were used as control. Cdc28 was probed with anti-PSTAIRE antibody as loading control. Fig 6B. Cells of wild type (S5314 or BWP17), pph34 (SJL3), rad534 (WY3), the rescued RAD53 (HT6) and the various strains expressing mutant alleles of RAD53 (HT13-16 rad53S461A, rad53-S461D, rad53-S545A, rad53-S545D) were were incubated at $30^{\circ} \mathrm{C}$ in YPD containing $20 \mathrm{mM} \mathrm{HU}$ and $0.02 \% \mathrm{MMS}$ for $4 \mathrm{~h}$, and then recovered with fresh YPD for $6 \mathrm{~h}$. RNA was extracted and reverse transcibed into CDNA for qPCR analysis. All data represent the mean of 3 independent experiments. ( ${ }^{*} P$ value $<0.01 ; * * P$ value $\left.<0.05\right)$. Fig $6 C$. Cells of wild type (HT1), pph3 $\Delta(H T 2)$ and the various $R A D 53$ mutants expressing C-terminally Myc-tagged Rfa2 (HT21-24 rad53-S461A Rfa2-myc, rad53-S461D Rfa2-myc, rad53-S545A Rfa2-myc and rad53-S545D Rfa2-myc) were incubated at $30^{\circ} \mathrm{C}$ in YPD containing $0.02 \%$ MMS for $4 \mathrm{~h}$ and recovered with fresh YPD over the indicated time period. Untreated cells were used as control. Total protein was extracted from harvested cells at the indicated time points and subject to immunoblot analysis with anti-Myc antibody. Cdc28 was probed with anti-PSTAIRE antibody as loading control.

doi:10.1371/journal.pone.0037246.g006

buffer [16]. After adding an equal volume of acid-washed glass beads (Sigma-Aldrich), the cells were lysed by four rounds of $45 \mathrm{~s}$ of beating at 5,000 rpm in a MicroSmash MS-100 bead beater (Tomy Medico, Minato-ku, Japan) with 2 min of cooling on ice between rounds. Cell lysate supernatant was collected after centrifugation at $13,000 \mathrm{rpm}$ for $20 \mathrm{~min}$ at $4^{\circ} \mathrm{C}$. Protein concentration of the lysate was determined using bicinchoninic acid (BCA) protein assay (Galen).
For Western blotting, $30 \mu \mathrm{g}$ of total protein was separated by $10 \%$ or $12 \%$ SDS-PAGE and transferred to a polyvinylidene difluoride (PVDF) membrane (Millipore). The membrane was immersed in Tris-buffered saline containing $0.1 \%$ Tween 20 (TBST) and 5\% non-fat dry milk for $1 \mathrm{~h}$ at room temperature, followed by primary antibody and secondary antibody conjugated with hydrogen peroxidase (HRP) or alkaline phosphatase (AP) consecutively for $1 \mathrm{~h}$ each, both in TBST containing $1 \%$ milk. The target protein was visualized by using an enhanced- 
chemiluminescence (ECL) system or Alkaline Phosphatase (AP) system. Anti-Myc and anti-Gdc28 (PSTAIRE) antibodies were puchased from Santa Cruz (USA).

Protein dephosphorylation was carried out as described previously [30]. Lambda phosphatase was purchased from New England BioLabs (catalog no. P07535).

\section{Microscopy and flow cytometry}

Staining of nuclei and chitin was carried out as previously described [5]. Zeiss 510 metamicroscope and Cell Observer system (Carl Zeiss MicroImaging, Germany) were used for imaging. Flow cytometry was performed on Flow Cytometer BD FACIV Vantage $^{\mathrm{TM}} \mathrm{SE}$ system as described previously [21].

\section{RNA isolation, RT-PCR, Northern blot and qPCR}

Total RNA was obtained as previously described [73]. cDNA was synthesized using the SuperScript II Reverse Transcriptase kit (Invitrogen). RT-PGR was done according to the description of Kelly, et al. (2004) [74]. Northern blot was performed according to the description of Lane, et al. (2001) [75]. qPCR was performed using the iQ SYBR Green Supermix (Bio-Rad) and detected via the iCycler iQ detection system (Bio-Rad). Oligonucleotide primers used to detect the transcripts of selected genes by RTPCR are shown in Table S1. qPCR was done using the following program: initial denaturation at $94^{\circ} \mathrm{C}$ for $5 \mathrm{~min}$, followed by 40 cycles of $94^{\circ} \mathrm{C}$ for $20 \mathrm{~s}, 56^{\circ} \mathrm{C}$ for $30 \mathrm{~s}$, and $68^{\circ} \mathrm{C}$ for $20 \mathrm{~s}$. Amplification specificity was determined by melting curve analysis.

\section{Supporting Information}

Table S1 Oligonucleotide primers used for Construct, RT-PGR and qPGR analysis.

(DOC)

Figure S1 pph3A and psy2A cells exhibit pseudohyphal growth upon MMS treatment. Fig S1. Wild-type (SC5314 or BWP17), pph34 (SJL3) and psy24 (SJL6) cells were grown in liquid YPD medium supplemented with $0.02 \%$ MMS at $30^{\circ} \mathrm{C}$ for $6 \mathrm{~h}$, washed with fresh YPD and resuspended into fresh YPD for further growth at $30^{\circ} \mathrm{C}$ for $8 \mathrm{~h}$. Cells were collected for microscopic examination at the indicated times. (Bar $=5 \mu \mathrm{m})$. (TIF)

Figure S2 pph34 and psy24 cells exhibit pseudohyphal growth upon HU treatment. Fig S2. Wild-type (SC5314 or BWP17), pph3 4 (SJL3) and psy2 4 (SJL6) cells were grown in liquid YPD medium supplemented with $20 \mathrm{mM} \mathrm{HU}$ at $30^{\circ} \mathrm{C}$ for $6 \mathrm{~h}$,

\section{References}

1. Berman J, Sudbery PE (2002) Candida Albicans: a molecular revolution built on lessons from budding yeast. Nat Rev Genet 3: 918-930.

2. Sudbery P, Gow N, Berman J (2004) The distinct morphogenic states of Candida albicans. Trends Microbiol 12: 317-324.

3. Odds FC (1994) Pathogenesis of Candida infections. J Am Acad Dermatol 31: $\mathrm{S} 2-5$.

4. Wightman R, Bates S, Amornrrattanapan P, Sudbery P (2004) In Candida albicans, the Niml kinases Gin4 and Hsll negatively regulate pseudohypha formation and Gin4 also controls septin organization. J Cell Biol 164: 581-591.

5. Zheng X, Wang Y (2004) Hgc1, a novel hypha-specific G1 cyclin-related protein regulates Candida albicans hyphal morphogenesis. EMBO J 23: 1845-1856.

6. Csank C, Makris C, Meloche S, Schroppel K, Rollinghoff M, et al. (1997) Derepressed hyphal growth and reduced virulence in a $\mathrm{VH} 1$ family-related protein phosphatase mutant of the human pathogen Candida albicans. Mol Biol Cell 8: 2539-2551.

7. Lo HJ, Kohler JR, DiDomenico B, Loebenberg D, Cacciapuoti A, et al. (1997) Nonfilamentous C, albicans mutants are avirulent. Cell 90: 939-949.

8. Gale CA, Bendel CM, McClellan M, Hauser M, Becker JM, et al. (1998) Linkage of adhesion, filamentous growth, and virulence in Candida albicans to a single gene, INT1. Science 279: 1355-1358. washed with fresh YPD and resuspended into fresh YPD for further growth at $30^{\circ} \mathrm{C}$ for $8 \mathrm{~h}$. Cells were collected for microscopic examination at the indicated times. (Bar $=5 \mu \mathrm{m})$.

(TIF)

Figure S3 Rad53p undergoes hyperphosphorylation in response to HU and MMS. Fig S3A Rad53 hyperphosphorylation in HU-treated cells. The lysate of SJL9 (wild-type with RAD53-Myc), SJL7 (pph3A RAD53-Myc), and SJL8 (psy2A $R A D 53-M y c$ ) cells that were incubated at $30^{\circ} \mathrm{C}$ in YPD containing $20 \mathrm{mM} \mathrm{HU}$ for $4 \mathrm{~h}$ was divided into 2 parts. One was treated with $\lambda$-phosphatase (PPase), and the other was mock-treated with the reaction buffer alone. The two samples, along with untreated cell lysates, were then subjected to Western blot analysis using antiMyc antibody. Fig S3B Rad53 hyperphosphorylation in MMStreated cells. The lysate of SJL9 (wild-type with RAD53-Myc), SJL7 (pph3A RAD53-Myc), and SJL8 (psy2A RAD53-Myc) cells that were incubated at $30^{\circ} \mathrm{C}$ in YPD containing $0.02 \%$ MMS for $4 \mathrm{~h}$ was divided into 2 parts. One was treated with $\lambda$-phosphatase (PPase), and the other was mock-treated with the reaction buffer alone. The two samples, along with untreated cell lysates, were then subjected to Western blot analysis using anti-Myc antibody. (TIF)

Figure S4 Detection of Rad53 hyperphosphorylation by Western blotting in pph $3 \Delta$ cells and cells expressing various mutant alleles of $R A D 53$ upon HU treatment. Fig S4. Wild-type (SJL9), pph3A (SJL7), and the various strains expressing C-terminally Myc-tagged mutant alleles of RAD53 (HT13.1-16.1 rad53-S461A, rad53-S461D, rad53-S545A, rad53$S 545 \mathrm{D}$ cells were incubated at $30^{\circ} \mathrm{C}$ in YPD containing $20 \mathrm{mM}$ $\mathrm{HU}$ for $4 \mathrm{~h}$, then washed and recovered with fresh YPD for the indicated times. Whole cell lysates were used for immunoblot analysis with anti-Myc antibody. Untreated cells were used as control. Cdc28 was probed with anti-PSTAIRE antibody as loading control.

(TIF)

\section{Acknowledgments}

We thank members of the Sang laboratory for comments and suggestions on the manuscript.

\section{Author Contributions}

Conceived and designed the experiments: HW JS YW. Performed the experiments: HW JG KH KC. Analyzed the data: HW AHW WL JS YW. Wrote the paper: AHW YW HW WL.

9. Gow NA, Brown AJ, Odds FC (2002) Fungal morphogenesis and host invasion. Curr Opin Microbiol 5: 366-371

10. Liu H, Kohler J, Fink GR (1994) Suppression of hyphal formation in Candida albicans by mutation of a STE12 homolog. Science 266: 1723-1726.

11. Liu H (2001) Transcriptional control of dimorphism in Candida albicans. Curr Opin Microbiol 4: 728-735.

12. Bai C, Ramanan N, Wang YM, Wang Y (2002) Spindle assembly checkpoint component CaMad2p is indispensable for Candida albicans survival and virulence in mice. Mol Microbiol 45: 31-44.

13. Bachewich G, Nantel A, Whiteway M (2005) Cell cycle arrest during S or M phase generates polarized growth via distinct signals in Candida albicans. Mol Microbiol 57: 942-959.

14. Bachewich C, Whiteway M (2005) Cyclin Cln3p links G1 progression to hyphal and pseudohyphal development in Candida albicans. Eukaryot Cell 4. 95-102.

15. Chapa y Lazo B, Bates S, Sudbery P (2005) The G1 cyclin Cln3 regulates morphogenesis in Candida albicans. Eukaryot Cell 4: 90-94.

16. Bensen ES, Clemente-Blanco A, Finley KR, Correa-Bordes J, Berman J (2005) The mitotic cyclins Clb2p and Clb4p affect morphogenesis in Candida albicans. Mol Biol Cell 16: 3387-3400. 
17. Bachewich C, Thomas DY, Whiteway M (2003) Depletion of a polo-like kinase in Candida albicans activates cyclase-dependent hyphal-like growth. Mol Biol Cell 14: 2163-2180.

18. Atir-Lande A, Gildor T, Kornitzer D (2005) Role for the SCFCDC4 ubiquitin ligase in Candida albicans morphogenesis. Mol Biol Cell 16: 2772-2785.

19. Andaluz E, Ciudad T, Gomez-Raja J, Calderone R, Larriba G (2006) Rad52 depletion in Candida albicans triggers both the DNA-damage checkpoint and filamentation accompanied by but independent of expression of hypha-specific genes. Mol Microbiol 59: 1452-1472.

20. Legrand M, Chan CL, Jauert PA, Kirkpatrick DT (2008) Analysis of base excision and nucleotide excision repair in Candida albicans. Microbiology 154: 2446-2456.

21. Shi OM, Wang YM, Zheng XD, Lee RT, Wang Y (2007) Critical role of DNA checkpoints in mediating genotoxic-stress-induced filamentous growth in Candida albicans. Mol Biol Cell 18: 815-826.

22. Allen JB, Zhou Z, Siede W, Friedberg EC, Elledge SJ (1994) The SAD1/ RAD53 protein kinase controls multiple checkpoints and DNA damage-induced transcription in yeast. Genes Dev 8: 2401-2415.

23. Bartek J, Falck J, Lukas J (2001) CHK2 kinase-a busy messenger. Nat Rev Mol Cell Biol 2: 877-886.

24. Liao H, Byeon IJ, Tsai MD (1999) Structure and function of a new phosphopeptide-binding domain containing the FHA2 of Rad53. J Mol Biol 294: 1041-1049.

25. Pike BL, Yongkiettrakul S, Tsai MD, Heierhorst J (2003) Diverse but overlapping functions of the two forkhead-associated (FHA) domains in Rad53 checkpoint kinase activation. J Biol Chem 278: 30421-30424.

26. Schwartz MF, Lee SJ, Duong JK, Eminaga S, Stern DF (2003) FHA domainmediated DNA checkpoint regulation of Rad53. Cell Cycle 2: 384-396.

27. Tercero JA, Diffley JF (2001) Regulation of DNA replication fork progression through damaged DNA by the Mec1/Rad53 checkpoint. Nature 412: 553-557.

28. Leroy G, Lee SE, Vaze MB, Ochsenbien F, Guerois R, et al. (2003) PP2C phosphatases Ptc2 and Ptc3 are required for DNA checkpoint inactivation after a double-strand break. Mol Cell 11: 827-835.

29. Keogh MC, Kim JA, Downey M, Fillingham J, Chowdhury D, et al. (2006) A phosphatase complex that dephosphorylates gammaH2AX regulates DNA damage checkpoint recovery. Nature 439: 497-501.

30. Vialard JE, Gilbert CS, Green CM, Lowndes NF (1998) The budding yeast Rad9 checkpoint protein is subjected to Mec1/Tell-dependent hyperphosphorylation and interacts with Rad53 after DNA damage. EMBO J 17: 5679-5688.

31. Grandin N, Bailly A, Charbonneau M (2005) Activation of Mrc1, a mediator of the replication checkpoint, by telomere erosion. Biol Cell 97: 799-814.

32. Sweeney FD, Yang F, Chi A, Shabanowitz J, Hunt DF, et al. (2005) Saccharomyces cerevisiae Rad9 acts as a Mecl adaptor to allow Rad53 activation. Curr Biol 15: 1364-1375.

33. Hastie CJ, Vazquez-Martin C, Philp A, Stark MJ, Cohen PT (2006) The Saccharomyces cerevisiae orthologue of the human protein phosphatase 4 core regulatory subunit $\mathrm{R} 2$ confers resistance to the anticancer drug cisplatin. FEBS J 273: 3322-3334.

34. O'Neill BM, Szyjka SJ, Lis ET, Bailey AO, Yates JR, 3rd, et al. (2007) Pph3Psy2 is a phosphatase complex required for Rad53 dephosphorylation and replication fork restart during recovery from DNA damage. Proc Natl Acad Sci U S A 104: 9290-9295.

35. Heideker J, Lis ET, Romesberg FE (2007) Phosphatases, DNA damage checkpoints and checkpoint deactivation. Cell Cycle 6: 3058-3064

36. Dotiwala F, Haase J, Arbel-Eden A, Bloom K, Haber JE (2007) The yeast DNA damage checkpoint proteins control a cytoplasmic response to DNA damage. Proc Natl Acad Sci U S A 104: 11358-11363.

37. Vidanes GM, Sweeney FD, Galicia S, Cheung S, Doyle JP, et al. (2010) CDC5 inhibits the hyperphosphorylation of the checkpoint kinase Rad53, leading to checkpoint adaptation. PLoS Biol 8: e1000286.

38. Sun LL, Li WJ, Wang HT, Chen J, Deng P, et al. (2011) The protein phosphatase Pph3 and its regulatory subunit Psy2 regulate Rad53 dephosphorylation and cell morphogenesis during recovery from DNA damage in Candida albicans. Eukaryot Cell.

39. Sidorova JM, Breeden LL (1997) Rad53-dependent phosphorylation of Swi6 and down-regulation of CLN1 and CLN2 transcription occur in response to DNA damage in Saccharomyces cerevisiae. Genes Dev 11: 3032-3045.

40. Cote P, Hogues H, Whiteway M (2009) Transcriptional analysis of the Candida albicans cell cycle. Mol Biol Cell 20: 3363-3373.

41. Koch C, Moll T, Neuberg M, Ahorn H, Nasmyth K (1993) A role for the transcription factors $\mathrm{Mbp} 1$ and Swi4 in progression from $\mathrm{Gl}$ to $\mathrm{S}$ phase. Science 261: 1551-1557

42. Iyer VR, Horak CE, Scafe CS, Botstein D, Snyder M, et al. (2001) Genomic binding sites of the yeast cell-cycle transcription factors SBF and MBF. Nature 409: 533-538.

43. Liu VF, Weaver DT (1993) The ionizing radiation-induced replication protein A phosphorylation response differs between ataxia telangiectasia and normal human cells. Mol Cell Biol 13: 7222-7231.

44. Carty MP, Zernik-Kobak M, McGrath S, Dixon K (1994) UV light-induced DNA synthesis arrest in HeLa cells is associated with changes in phosphorylation of human single-stranded DNA-binding protein. EMBO J 13: 2114-2123.

45. Niu H, Erdjument-Bromage H, Pan ZO, Lee SH, Tempst P, et al. (1997) Mapping of amino acid residues in the p34 subunit of human single-stranded
DNA-binding protein phosphorylated by DNA-dependent protein kinase and Cdc2 kinase in vitro. J Biol Chem 272: 12634-12641.

46. Zernik-Kobak M, Vasunia K, Connelly M, Anderson CW, Dixon K (1997) Sites of UV-induced phosphorylation of the p34 subunit of replication protein A from HeLa cells. J Biol Chem 272: 23896-23904.

47. Oakley GG, Loberg LI, Yao J, Risinger MA, Yunker RL, et al. (2001) UVinduced hyperphosphorylation of replication protein a depends on DNA replication and expression of ATM protein. Mol Biol Cell 12: 1199-1213.

48. Block WD, Yu Y, Lees-Miller SP (2004) Phosphatidyl inositol 3-kinase-like serine/threonine protein kinases (PIKKs) are required for DNA damageinduced phosphorylation of the $32 \mathrm{kDa}$ subunit of replication protein $\mathrm{A}$ at threonine 21. Nucleic Acids Res 32: 997-1005.

49. Bazzi M, Mantiero D, Trovesi C, Lucchini G, Longhese MP (2010) Dephosphorylation of gamma H2A by Glc7/protein phosphatase 1 promotes recovery from inhibition of DNA replication. Mol Cell Biol 30: 131-145.

50. Verma R, Smiley J, Andrews B, Campbell JL (1992) Regulation of the yeast DNA replication genes through the MluI cell cycle box is dependent on SWI6. Proc Natl Acad Sci USA. pp 9479-9483.

51. Foord R, Taylor IA, Sedgwick SG, Smerdon SJ (1999) X-ray structural analysis of the yeast cell cycle regulator Swi6 reveals variations of the ankyrin fold and has implications for Swi6 function. Nat Struct Biol 6: 157-165.

52. Bean JM, Siggia ED, Cross FR (2005) High functional overlap between MluI cell-cycle box binding factor and Swi4/6 cell-cycle box binding factor in the G1/ S transcriptional program in Saccharomyces cerevisiae. Genetics 171: 49-61.

53. Truman AW, Kim KY, Levin DE (2009) Mechanism of Mpk1 mitogenactivated protein kinase binding to the Swi4 transcription factor and its regulation by a novel caffeine-induced phosphorylation. Mol Cell Biol 29: 6449-6461.

54. Ferrezuelo F, Colomina N, Futcher B, Aldea M (2010) The transcriptional network activated by $\mathrm{Cln} 3$ cyclin at the G1-to-S transition of the yeast cell cycle. Genome Biol 11: R67.

55. Hussein B, Huang H, Glory A, Osmani A, Kaminskyj S, et al. (2011) G1/S transcription factor orthologues Swi4p and Swi6p are important but not essential for cell proliferation and influence hyphal development in the fungal pathogen Candida albicans. Eukaryot Cell 10: 384-397.

56. Brill SJ, Stillman B (1991) Replication factor-A from Saccharomyces cerevisiae is encoded by three essential genes coordinately expressed at $\mathrm{S}$ phase. Genes Dev 5: 1589-1600.

57. Maniar HS, Wilson R, Brill SJ (1997) Roles of replication protein-A subunits 2 and 3 in DNA replication fork movement in Saccharomyces cerevisiae. Genetics 145: 891-902.

58. Santocanale C, Neecke H, Longhese MP, Lucchini G, Plevani P (1995) Mutations in the gene encoding the $34 \mathrm{kDa}$ subunit of yeast replication protein A cause defective S phase progression. J Mol Biol 254: 595-607.

59. Smolka MB, Albuquerque CP, Chen SH, Schmidt KH, Wei XX, et al. (2005) Dynamic changes in protein-protein interaction and protein phosphorylation probed with amine-reactive isotope tag. Mol Cell Proteomics 4: 1358-1369.

60. Usui T, Foster SS, Petrini JH (2009) Maintenance of the DNA-damage checkpoint requires DNA-damage-induced mediator protein oligomerization. Mol Cell 33: 147-159.

61. Lee H, Yuan C, Hammet A, Mahajan A, Chen ES, et al. (2008) Diphosphothreonine-specific interaction between an SO/TO cluster and an FHA domain in the Rad53-Dun1 kinase cascade. Mol Cell 30: 767-778.

62. Ma JL, Lee SJ, Duong JK, Stern DF (2006) Activation of the checkpoint kinase Rad53 by the phosphatidyl inositol kinase-like kinase Mec1. J Biol Chem 281: 3954-3963.

63. Sweeney FD (2009) ORCHESTRATION OF THE DNA DAMAGE CHECKPOINT RESPONSE THROUGH THE REGULATION OF THE PROTEIN KINASE RAD53. thesis. pp 132-133.

64. Usui T, Petrini JH (2007) The Saccharomyces cerevisiae 14-3-3 proteins Bmh1 and Bmh2 directly influence the DNA damage-dependent functions of Rad53. Proc Natl Acad Sci U S A 104: 2797-2802.

65. Gilbert CS, Green CM, Lowndes NF (2001) Budding yeast Rad9 is an ATPdependent Rad53 activating machine. Mol Cell 8: 129-136.

66. Ahn JY, Li X, Davis HL, Canman CE (2002) Phosphorylation of threonine 68 promotes oligomerization and autophosphorylation of the Chk2 protein kinase via the forkhead-associated domain. J Biol Chem 277: 19389-19395.

67. Lee SJ, Schwartz MF, Duong JK, Stern DF (2003) Rad53 phosphorylation site clusters are important for Rad53 regulation and signaling. Mol Cell Biol 23: $6300-6314$

68. Xu X, Tsvetkov LM, Stern DF (2002) Chk2 activation and phosphorylationdependent oligomerization. Mol Cell Biol 22: 4419-4432.

69. Jia-Lin Ma N, Stern DF (2008) Regulation of the Rad53 protein kinase in signal amplification by oligomer assembly and disassembly. Cell Cycle 7: 808-817.

70. Wilson RB, Davis D, Mitchell AP (1999) Rapid hypothesis testing with Candida albicans through gene disruption with short homology regions. J Bacteriol 181: $1868-1874$

71. Enloe B, Diamond A, Mitchell AP (2000) A single-transformation gene function test in diploid Candida albicans. J Bacteriol 182: 5730-5736.

72. Morschhauser J, Michel S, Staib P (1999) Sequential gene disruption in Candida albicans by FLP-mediated site-specific recombination. Mol Microbiol 32: 547-556.

73. De Las Penas A, Pan SJ, Castano I, Alder J, Cregg R, et al. (2003) Virulencerelated surface glycoproteins in the yeast pathogen Candida glabrata are 
encoded in subtelomeric clusters and subject to RAP1- and SIR-dependent transcriptional silencing. Genes Dev 17: 2245-2258.

74. Kelly MT, MacCallum DM, Clancy SD, Odds FC, Brown AJ, et al. (2004) The Candida albicans CaACE2 gene affects morphogenesis, adherence and virulence. Mol Microbiol 53: 969-983.
75. Lane S, Birse C, Zhou S, Matson R, Liu H (2001) DNA array studies demonstrate convergent regulation of virulence factors by $\mathrm{Cph} 1, \mathrm{Cph} 2$, and Efg1 in Candida albicans. J Biol Chem 276: 48988-48996. 